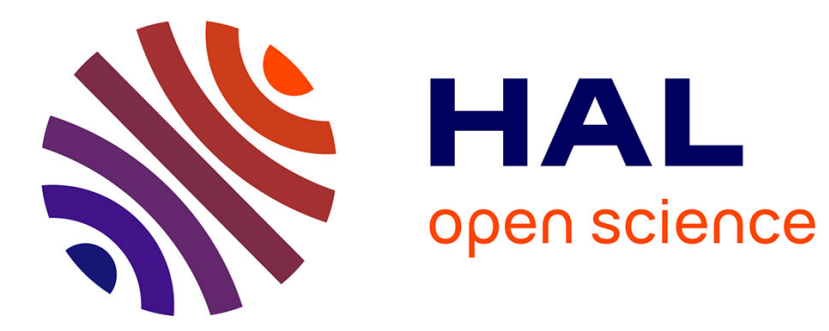

\title{
Total column ozone variations over oceanic region around Indian sub-continent during pre-monsoon of 2006
}

\author{
M. C. R. Kalapureddy, P. Ernest Raj, P. C. S. Devara
}

\section{To cite this version:}

M. C. R. Kalapureddy, P. Ernest Raj, P. C. S. Devara. Total column ozone variations over oceanic region around Indian sub-continent during pre-monsoon of 2006. Atmospheric Chemistry and Physics Discussions, 2008, 8 (1), pp.3143-3162. hal-00303974

\section{HAL Id: hal-00303974 \\ https://hal.science/hal-00303974}

Submitted on 14 Feb 2008

HAL is a multi-disciplinary open access archive for the deposit and dissemination of scientific research documents, whether they are published or not. The documents may come from teaching and research institutions in France or abroad, or from public or private research centers.
L'archive ouverte pluridisciplinaire HAL, est destinée au dépôt et à la diffusion de documents scientifiques de niveau recherche, publiés ou non, émanant des établissements d'enseignement et de recherche français ou étrangers, des laboratoires publics ou privés. 
Total ozone over oceanic regions

M. C. R. Kalapureddy et al.

\section{Total column ozone variations over oceanic region around Indian sub-continent during pre-monsoon of 2006}

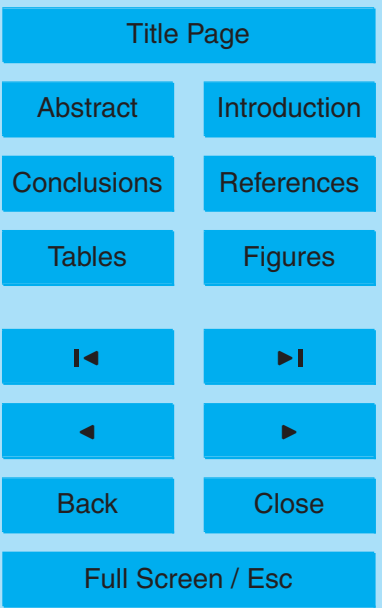

M. C. R. Kalapureddy, P. Ernest Raj, and P. C. S. Devara

Indian Institute of Tropical Meteorology, Pashan, Pune 411 008, India

Received: 13 November 2007 - Accepted: 11 January 2008 - Published: 14 February 2008

Correspondence to: P. Ernest Raj (ernest@tropmet.res.in) 


\section{Abstract}

Special campaign mode ship-based sun photometric observations of total column ozone over the oceanic regions around the Indian sub-continent $\left(56^{\circ} \mathrm{E}-6^{\circ} \mathrm{E}, 4^{\circ} \mathrm{N}-{ }^{\circ} \mathrm{N}\right)$ during the pre-monsoon period (18 March-11 May) of 2006 have been used to inves5 tigate the spatial and temporal distributions. The overall mean ozone content over the sea region during this period is $298 \mathrm{DU}$ with a variability of $\pm 10 \mathrm{DU}$. There is a well defined diurnal (daytime) variation in total column ozone with maximum content around the noon-time hours. The amplitude of diurnal variation is higher over the Arabian Sea compared to that over Bay of Bengal. Spatial distribution of total ozone shows higher values over the Head Bay (North Bay of Bengal) and all along the west coast of India strongly pointing to continental origin of possible anthropogenic source. This is further corroborated from the spatial distribution of simultaneously measured aerosol optical thickness (AOT, at $1020 \mathrm{~nm}$ ) and precipitable water. The overall mean AOT over the oceanic region is 0.09 and mean precipitable water (water vapor) over Indian Ocean 15 region was $3.25 \mathrm{~cm}$ which is almost $1 \mathrm{~cm}$ higher than that observed over Bay of Bengal and Arabian Sea during the above pre-monsoon period.

\section{Introduction}

Concentrations of ozone $\left(\mathrm{O}_{3}\right)$ in the atmosphere can change as a result of both natural processes and human activities. Changes in stratospheric ozone are related to changes in tropospheric source gases, variations in solar radiation, volcanic events, and to changes in large scale transport. Changes in tropospheric ozone are mainly associated with increase in human activity especially urban pollution and biomass burning. Also ozone is transported downward from the stratosphere, but the main source in the troposphere is in situ photochemical $\mathrm{O}_{3}$ formation through oxidation of carbon compounds, which is catalyzed and controlled by nitrogen oxides. The main sources of $\mathrm{NO}_{\mathrm{x}}$ in turn, are fossil fuel combustion, biomass burning, lightning and soil microbial

Total ozone over oceanic regions

M. C. R. Kalapureddy et al.

Title Page

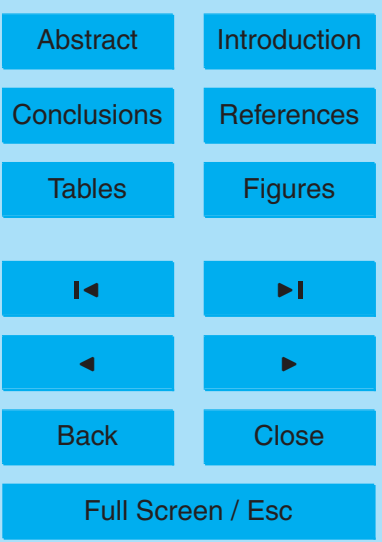

Printer-friendly Version

Interactive Discussion 
activity. Stratospheric ozone has decreased over the last several decades, while tropospheric ozone has increased over the Northern Hemisphere midlatitudes (Logan et al., 1999). About $40 \%$ of the global ozone is located in the tropics between $25^{\circ} \mathrm{N}$ and $25^{\circ} \mathrm{S}$, and a strong decadal variation of total ozone in the tropics with maxima approximately

5 in phase with the 11 year solar cycle has been documented (World Meteorological Organization, 2003). Also statistically significant negative trends in total ozone were found at all latitudes except possibly in the tropics, where ground-based measurements show no long term trends (Madronich et al., 1994). From total column ozone data (Dobson spectrophotometer) for the period 1957-1994, Chakrabarty et al. (1998) 10 have found no long-term trend over the Indian tropical station, Pune. However, the Dobson ozone data of the same station for the period 1981-1998 showed a decreasing trend (Londhe et al., 2003). The impacts of changing air quality are largely felt through photochemical smog, in which trophospheric ozone plays a key role, through the increasing concentration of aerosol particles and the potential impacts of increasing UV-B radiation caused by the loss of stratospheric ozone. The changes in the earth's ozone layer due to anthropogenic activities and geological events significantly impact our biosphere. The seasonal variation of Total Ozone over India almost resembled the typical feature for low latitude stations characterized by a winter minimum and a summer maximum. Moreover, seasonal variation of surface ozone compared with that for Total Ozone may not show any correlation implying the role of vertical transport of ozone over the concerned location. Several measurements made during NASA's Global Tropospheric Experiment program over the Pacific and Atlantic Oceans have reported distinct pollution plumes of tropospheric ozone and its precursors in the middle and upper troposphere (e.g., Chameides et al., 1989; Davis et al., 1996; Fishman et al., 1996; Singh et al., 1996, 2000; Schultz et al., 1999). The photochemical destruction of ozone due to this mechanism has been found to be important over the marine boundary layer (MBL) of the central Atlantic Ocean also (Weller et al., 1996). However, in the middle and upper troposphere of the Pacific and Atlantic Oceans, instances of elevated levels of ozone and its precursors like $\mathrm{CO}$ and $\mathrm{NO}_{\mathrm{x}}$ have been

Total ozone over oceanic regions

M. C. R. Kalapureddy et al.

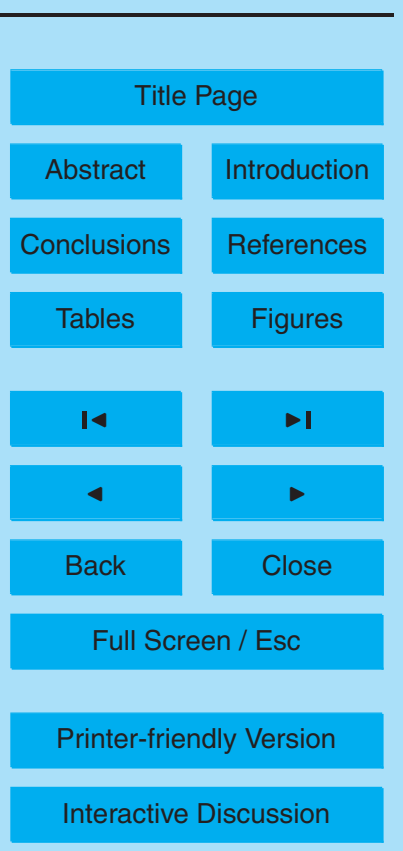


reported by Prados et al. (1999). Two ways to measure ozone in the atmosphere are measurement of total column ozone and measurement of the vertical distribution of ozone. Regular measurements of total column ozone are available from a network of surface stations, mostly in the mid latitude Northern Hemisphere, with reasonable 5 temporal coverage extending back to the 1960s. Near-global, continuous total ozone data are available from satellite measurements since 1979. The ratio of the intensity of direct sunlight at two wavelengths in the $300-320 \mathrm{~nm}$ range is a measure of the total abundance of ozone in a column through the atmosphere. This forms the basic operating principle for a variety of optical instruments that monitor atmospheric ozone. The 10 ground-based ozone monitoring instruments Dobson and Brewer spectrophotometers are universally accepted for measuring column ozone but are expensive, heavy, and large in dimension. There has been a need for a more portable and compact instrument that can measure ozone with reasonable accuracy. A handheld, advanced filter ozonometer (Microtops-II) has been used by Ernest Raj et al. (2004) to measure total ozone and its variability on daily, monthly and seasonal scales at the tropical urban location, Pune. In the present study, using the same ozonometer, total ozone variations over the oceanic region around the Indian sub-continent region (around the east and west coast of India and adjoining Bay of Bengal, Indian Ocean and Arabian Sea) made during pre-monsoon season (March-May) of 2006 as part of Indian Space Research Organization (ISRO) organized "Integrated Campaign for Aerosols, gases and Radiation Budget (ICARB-06)" experiment are presented and discussed.

\section{Observations and database}

The ship cruise of Sagar Kanya Indian Research Vessel (SK223) under ICARB-06 program during the period 09 March-1 May 2006 started on the east coast of India from 25 Chennai Port $\left(13.1^{\circ} \mathrm{N}, 80.3^{\circ} \mathrm{E}\right)$ on 18 March. The cruise track over the marine region around the Indian sub-continent with dates during March-May 2006 (indicated as M, A, My) are shown in Fig. 1. The cruise initially extended in the north-east/eastward di-

Total ozone over oceanic regions

M. C. R. Kalapureddy et al.

\section{Title Page}

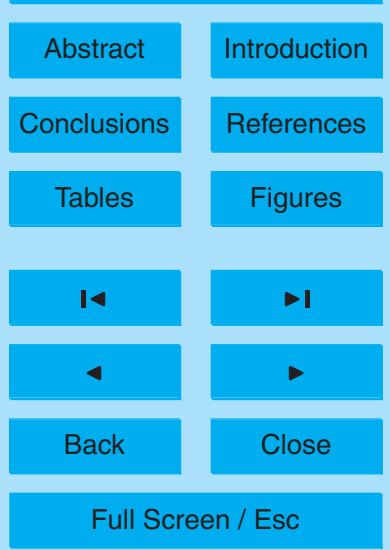

Printer-friendly Version

Interactive Discussion 
rection and reached the farthest point on the east $\left(14.8^{\circ} \mathrm{N}, 92.6^{\circ} \mathrm{E}\right)$ over Bay of Bengal (BoB) on 26 March 2006. After covering various parts of BoB it reached Kochi port $\left(9.9^{\circ} \mathrm{N}, 76.2^{\circ} \mathrm{E}\right)$ on the west coast on 13 April 2006 while traversing through some part of the northern Indian Ocean. Thus the first leg of observations conducted over the 5 BoB during March-April 2006 was for 24 days. Climate of the Bay of Bengal is influenced by three types of air flow; flow from Indian Subcontinent, flow South-East Asia, flow from Indian Ocean. During this observational period, general wind flows were from the East Asia and south China over the BoB and the west Asian transport is weak over the Arabian Sea. So, transport of air mass over this oceanic region could be mainly 10 from the Indian sub-continent. The second leg started on the west coast from Kochi on 18 April to cover western part of the Arabian Sea (AS) and ended after 23 days at Goa port $\left(15.4^{\circ} \mathrm{N}, 73.8^{\circ} \mathrm{E}\right)$ on 11 May. It reached its farthest point on the west $\left(14^{\circ} \mathrm{N}\right.$, $\left.59.4^{\circ} \mathrm{E}\right)$ over the AS on 3 May 2006 . The track of the ship cruise was designed in such a way that the maximum possible marine regions were covered during the period for 5 observations.

High temporal resolution observations of aerosol, ozone, and precipitable water were made using the hand-held sunphotometer/ozonometer (Microtops-II, Solar Light Company, USA). The ozonometer measures total column ozone (DU), columnar water vapor $(\mathrm{cm})$ and Aerosol Optical Thickness (AOT) at $1020 \mathrm{~nm}$ derived from instantaneous solar flux measurements during daytime. A Global Positioning System (GPS) receiver attached with the photometer provides time, latitude, and longitude information. Details of the ozonometer, retrieval methods and measurement accuracies are described elsewhere (Morys et al., 2001; Porter et al., 2001; Ichoku et al., 2002; Ernest Raj et al., 2004). In the present experiment at every 10 minutes interval, three sets of pointing on a moving platform. If the three measured values of any parameter are not close in magnitude, the data set is rejected from further analysis. The instrument has been recently calibrated and before the actual campaign measurements started, an inter calibration/comparison of several similar ozonometers operated aboard the ship

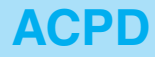

8, 3143-3162, 2008

Total ozone over oceanic regions

M. C. R. Kalapureddy et al.

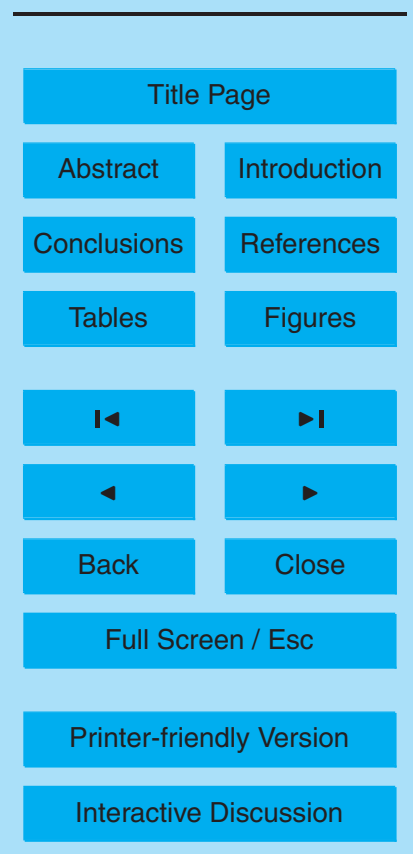

EGU 
by different organizations was undertaken to ensure the reliability of measurements. Data recorded around cloud passage on or near the field-of-view (FOV) have not been considered for the analysis.

\section{Results and discussions}

5 The entire data collected during the campaign is grouped into three zones, namely Bay of Bengal (BoB), Indian Ocean (IO) and Arabian Sea (AS) regions and the overall average total column ozone, precipitable water and AOT at $1020 \mathrm{~nm}$ for the entire cruise period and also region-wise means are shown in Table 1. The overall mean ozone content over the oceanic regions around India is $298 \mathrm{DU}$ during the pre-monsoon season (March-May) of 2006. Over the Bay of Bengal region it appears to be relatively lower by about 20 DU compared to that over Indian Ocean and Arabian Sea regions. However this difference could be primarily due to the seasonal increasing trend in the pre-monsoon months, because the observations over BoB were made during March and April and over AS were made during April and May. Variability in total ozone is nearly same (about $\pm 10 \mathrm{DU}$ ) over all the three regions. Figure 2 shows the high time resolution (10 min interval) data of total ozone (bottom panel) and the corresponding daily mean total ozone (top panel) collected by the ozonometer during the entire ship cruise period. It is interesting to see the significant diurnal variation (daytime) in total ozone with a well defined maximum during noontime. Also the amplitude of diurnal variation seems to increase as the ship moves over to the North Indian Ocean region and Arabian Sea from the Bay of Bengal. Though such a daytime temporal variation was reported for the continental station Pune during the month of April (Ernest Raj et al., 2004), it was not as smooth and systematic as it is now observed over the oceanic regions. Daily total ozone observed by Aura Ozone Monitoring Instrument (AOMI)25 TOMS (Total Ozone Mapping Spectrometer) like satellite (hereafter AOMI) has been collected for the corresponding geographical position and compared with the present daily mean observations obtained from the ship-based ozonometer (Fig. 2 top panel).

Total ozone over oceanic regions

M. C. R. Kalapureddy et al.

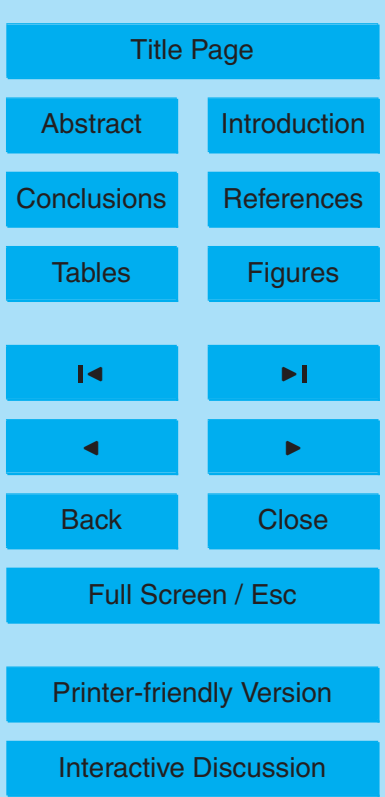

EGU 
The ship-based ozonometer overestimates AOMI retrieved column ozone by almost 23 DU but the day-to-day variations are very much in phase with each other. The difference in magnitude could be due to the fact that Ozonometer observations are made from a platform close to earth's surface and pointing skywards and the daily values 5 are average of 50-60 observations collected from morning to evening. The satellite is downward pointed and the ozone values are instantaneous during the passage of the satellite over the particular location. The overall mean aerosol optical thickness at $1020 \mathrm{~nm}$ over the oceanic region is low ( 0.09) compared to that over land regions, as expected, but its variability is high $( \pm 0.06)$. Mean precipitable water over Indian Ocean 10 region is $(3.25 \mathrm{~cm})$ higher by almost $1 \mathrm{~cm}$ compared to that over $B o B(2.25 \mathrm{~cm})$ and AS $(2.22 \mathrm{~cm})$ with an overall variability of \pm 0.64 . The high resolution ozone data collected over the three regions is grouped and the mean daytime temporal variations over $\mathrm{BoB}, \mathrm{IO}$ and $\mathrm{AS}$ regions together with the overall mean over these oceanic regions are shown in Fig. 3. Since the observations have been made in different longitude (time) zones, for comparison, the time scale here is shown in (Universal Coordinated Time) UTC. It is observed that there is a systematic smooth increase of column ozone in the forenoon and a decrease in the afternoon hours. The amplitude of diurnal variation is higher $(11.1 \%$ and $5.8 \%)$ over the $\mathrm{IO}$ and $\mathrm{AS}$ regions compared to that over $\mathrm{BoB}$ $(4.3 \%)$. The rate of increase of ozone content from post-sunrise to noon-time hours is highest over the Indian Ocean region. The overall diurnal variation is around $7.8 \%$ over oceanic regions around India.

The spatial distribution of total ozone over the oceanic regions around the Indian sub-continent $\left(56^{\circ} \mathrm{E}-96^{\circ} \mathrm{E}, 4^{\circ} \mathrm{N}-26^{\circ} \mathrm{N}\right)$ during the pre-monsoon season is shown in Fig. 4. Total ozone over Arabian Sea apparently appears to be higher by nearly $20 \mathrm{DU}$ than that over the Bay of Bengal. But as mentioned above, this could be mainly due to the seasonal increasing trend from March to May. However there are pockets of higher ozone content over the oceanic region. In BoB relatively higher ozone content is observed in the Head Bay close to the thickly populated Bengal coastal region. In the AS higher ozone content is found all along the west coast and also in some regions in the

Total ozone over oceanic regions

M. C. R. Kalapureddy et al.

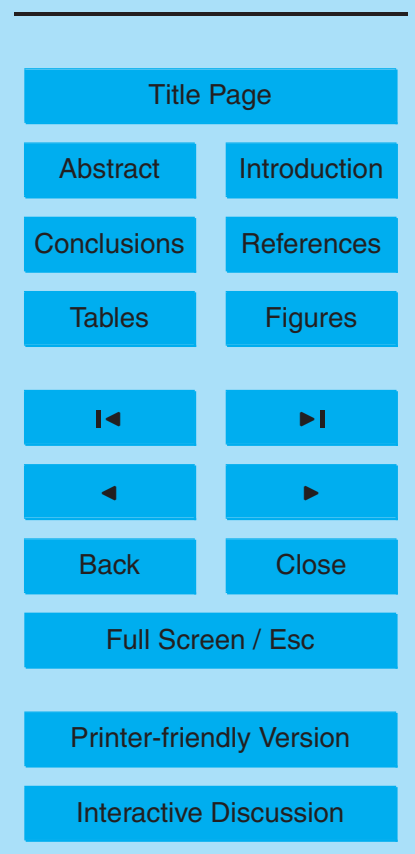

EGU 
deep sea. These aspects can be further confirmed from AOMI satellite ozone content observations over the same Indian sub-continent region shown in Figure $5 \mathrm{a}$ for the period 18 March-10 April 2006 and in Fig. 5b for the period 18 April-10 May 2006 for the geographical region $50^{\circ} \mathrm{E}-100^{\circ} \mathrm{E}, 0^{\circ} \mathrm{N}-30^{\circ} \mathrm{N}$. Satellite data also shows that during the 5 entire pre-monsoon period there is a region over the Head Bay close to the Bengal region where enhanced ozone content is seen. In fact this higher ozone content region is an extension, right into the oceanic region, of the thick band of enhanced ozone content all along the Indo-Gangetic plain in the latitude band $24^{\circ} \mathrm{N}-30^{\circ} \mathrm{N}$. This continental region is thickly populated with people engaged in agricultural activity, biomass burning 10 and there are also several developing urban centers. Fishman et al. (2003) investigated the spatial distribution of tropospheric ozone retrieved from TOMS (Total Ozone Mapping Spectrometer) and SBUV (Solar Backscatter Ultraviolet) measurements and showed enhanced ozone over northern India along the Gangetic valley and related it to population density. Ship-borne measurements over Atlantic Ocean by Lelieveld et 15 al. (2004) showed large $\mathrm{O}_{3}$ trends at low latitudes and southern hemisphere and nearsurface $\mathrm{O}_{3}$ increased up to a factor of 2 . They have indicated that the likely cause could be the substantial increase of anthropogenic emission of nitrogen oxides associated with energy use in Africa, added to $\mathrm{NO}_{\mathrm{x}}$ from biomass burning and natural sources. Aircraft experiments over Western Pacific (Tatsumi et al., 1996) showed that air originating from the Pacific Ocean showed lower concentration of ozone compared to the one that came from the Eurasian continent. A sharp gradient of the ozone concentration was observed around $10^{\circ}-25^{\circ} \mathrm{N}$; to the north of this gradient, air mass with high ozone and low water vapor of continental origin was found by them. Also the air mass which came from the middle of Australia showed high concentration of ozone. If 25 the emissions of $\mathrm{NO}_{x}$ take place in air that is still relatively pristine, the $\mathrm{O}_{3}$ formation per unit $\mathrm{NO}_{\mathrm{x}}$ added is much more efficient than in $\mathrm{NO}_{\mathrm{x}}$-enriched air (Liu et al., 1987; Trainer et al., 2000). The spatial distribution of ozone content over the oceanic regions around the Indian sub-continent thus seems to suggest a significant contribution from surface layers and in turn on the influence of human activity and dependence on the

Total ozone over oceanic regions

M. C. R. Kalapureddy et al.

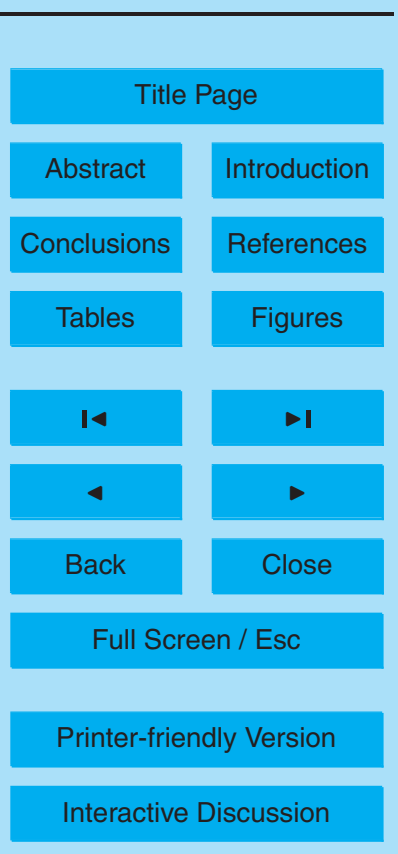


prevailing wind field.

The continental origin of excess ozone in the lower troposphere is further corroborated by the simultaneous observations of aerosol optical thickness at $1020 \mathrm{~nm}$ shown in Figure 6. Here one can see the regions of enhanced aerosol content in the Head Bay 5 and all along the west coast of the Indian sub-continent where enhanced total column ozone was observed during the pre-monsoon period. Interestingly the observations made in the deep oceanic regions far away from land regions showed smaller AOT values, implying that in terms of aerosols of continental origin, the deep oceans are still pristine. But ozone and its precursors can be transported to farther pristine oceanic 10 regions. Of course the prevailing wind speed and wind direction influence the transport and distribution of aerosols and gases far from the source regions. Figure 7 shows the spatial distribution of precipitable water/water vapor (WV) over the same marine region. It is observed that relatively Bay of Bengal and Arabian Sea regions show smaller values of WV $(1.5-2.5 \mathrm{~cm})$ compared to that over the Indian Ocean region to the south of the Indian sub-continent $(>2.5 \mathrm{~cm})$. Ozone can be photochemically destroyed by high water vapor concentration in the boundary layer but the interrelations over the oceanic regions are not fully understood.

\section{Conclusions}

Ship-borne sun photometric measurements of total column ozone, aerosol optical 20 thickness and precipitable water over the oceanic regions (comprising Bay of Bengal, Arabian Sea and northern Indian Ocean) around the Indian sub-continent made during the pre-monsoon period (March-May 2006) as part of a national observational campaign showed some interesting results. The overall mean ozone content over this oceanic region was $298 \mathrm{DU}$ with a variability of $\pm 10 \mathrm{DU}$. A systematic diurnal (daytime time hours and minima during morning and evening hours. The amplitude of diurnal variation was higher over the Arabian Sea region. Spatial distribution of ozone content

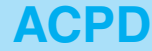

8, 3143-3162, 2008

Total ozone over oceanic regions

M. C. R. Kalapureddy et al.

Title Page

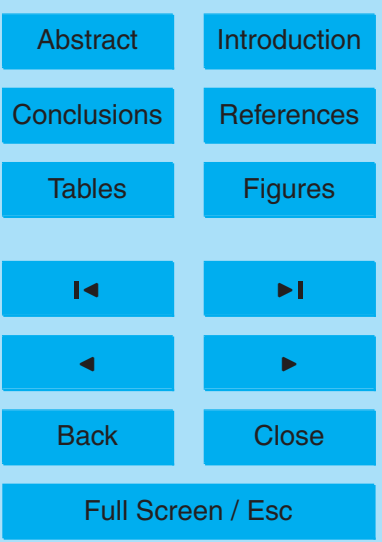

Printer-friendly Version

Interactive Discussion 
revealed higher values over Head Bay close to Bengal coastal region and all along the west coast of Indian peninsula. This strongly points to possible influence of human activity as these continental regions have high population density with activities like fossil fuel and biomass burning. This is further confirmed from simultaneously measured 5 aerosol content and its spatial distribution. The overall mean AOT at $1020 \mathrm{~nm}$ over the oceanic region was 0.09 which is low compared to that observed over the continental regions. Mean precipitable water over Bay of Bengal and Arabian Sea was about $2.25 \mathrm{~cm}$ and that over Indian Ocean region was $3.25 \mathrm{~cm}$. The study points out that in addition to stratosphere-troposphere exchange, substantial amount of anthropogenic ozone transported from continental region contributes to the total column ozone over the oceanic regions surrounding the Indian sub-continent.

Acknowledgements. Authors are thankful to Director, IITM for his encouragement. This work was supported by the ISRO-GBP-ICARB project and the efforts of the ICARB project team are highly appreciated. Authors are thankful to NCAOR/DOD, M. Sudhakar, for the ship and 15 onboard facilities and also to the Sagar Kanya cruise members for their excellent support and co-operation.

\section{References}

Angstrom, A. K.: The parameters of atmospheric turbidity, Tellus, 16, 64-75, 1964.

Chakrabarty, D. K., Peshin, S. K., Pandya, K. V., and Shah, N. C.: Long-term trend of ozone column over the Indian region, J. Geophys. Res., 103, 19245-19251, 1998.

Chameides, W. L., Davis, D. D., Gregory, G. L., Sachse,G., and Torres,A. L.: Ozone precursors and ozone photochemistry over eastern North Pacific during the spring of 1984 based on the NASA GTE/CITE 1 airborne observations, J. Geophys. Res., 94, 9799-9808, 1989.

Davis, D., Crawford, J., Liu, S., Mckeen, S., Bandy, A., Thornton, D., Rowland, F., and Blake, 25 D.: Potential impact of iodine on tropospheric levels of ozone and other critical oxidants, J. Geophys. Res., 101, 2135-2147, 1996.

Ernest Raj, P., Devara, P. C. S., Pandithurai, G., Maheskumar, R. S., Dani, K. K., Saha, S. K., and Sonbawne, S. M.: Variability in sun photometer-derived total ozone over a tropical urban station, J. Geophys. Res., 109, D08309, doi:10.1029/2003JD004195, 2004.

Total ozone over oceanic regions

M. C. R. Kalapureddy et al.

Title Page

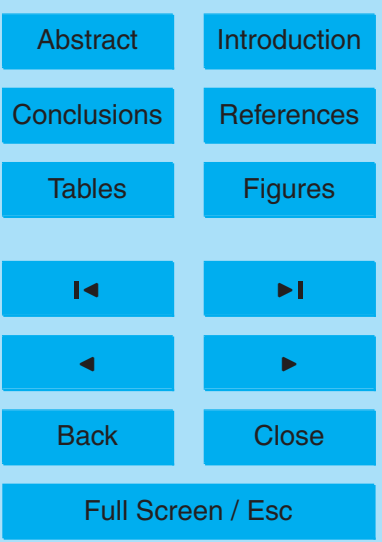

Printer-friendly Version

Interactive Discussion 
Fishman, J., Hoell, M. Jr., Bendura, R. D., McNeal, R. J., and Kirchoff, V. W. J. H.: NASA GTE TRACE A Experiment (September-October 1992): Overview, J. Geophys. Res., 101, 23 865-23 879, 1996.

Fishman, J., Wozniak, A. E., and Creilson, J. K.: Global distribution of tropospheric ozone from satellite measurements using the empirically corrected tropospheric ozone residual technique: Identification of the regional aspects of air pollution, Atmos. Chem. Phys., 3, 893-907, 2003 ,

http://www.atmos-chem-phys.net/3/893/2003/.

Ichoku, C, Levy R., Kaufman, Y. J., Remer, La. A., et al.: Analysis of the performance characteristics of the five-channel Microtops II Sun photometer for measuring aerosol optical thickness and precipitable water vapor, J. Geophys. Res. 107(D13), 4179, doi:10.1029/2001JD001302, 2002.

Lelieveld, J., van Aardenne, J., Fischer, H., de Reus, M., Williams, J., and Winker, P.: Increasing ozone over the Atlantic Ocean, Science, 304, 1483-1487, 2004.

Liu, S. C., Trainer, M., Fehsenfeld, F. C., Parrish, D. D., Williams, E. J., Fahey, D. W., Hubler, G., and Murphy, P. C.: Ozone production in the rural troposphere and their implications for regional and global ozone distributions, J. Geophys. Res., 92, 4191-4207, 1987.

Logan, J. A., Megretskaia, I. A., Miller, A. J., Tiao, G. C., et al.: Trends in the vertical distribution of ozone: A comparison of two analyses of ozonesonde data, J. Geophys. Res., 104, $26373-$ $20 \quad 26399,1999$.

Londhe, A. L.,Bhosale, C. S., Kulkarni, J. R., Kumari, B. P., and Jadhav, D. B.: Space-time variability of ozone over Indian region for the period 1981-1998, J. Geophys. Res., 108(D24), 8781, doi:10.1029/2002JD002942, 2003.

Madronich, S., Mckenzie, R. L., Caldwell, M. M., and Bjorn, L. O.: Changes in ultraviolet radiation reaching the Earth's surface, in Environ-mental Effects of Ozone Depletion-1994 Assessment, report, chap. 1, 1-22, U. N. Environ. Prog., Nairobi, Kenya, 1994.

Morys, M., Mims III, F. M., Hagerup, S., Anderson, S. E., Baker, A., Kia, J., and Walkup, T.: Design, calibration, and performance of MICROTOPS II handheld ozone monitor and sun photometer, J. Geophys. Res., 106, 14573-14582, 2001.

30 Porter, J. N., Miller, M., Pietras, C., and Motell, C.: Ship based sun photometer measurements using Microtops sun photometer, J. Atmos. Oceanic. Technol., 18, 765-774, 2001.

Prados, A. I., Dickerson, R. R., Doddridge, B. G., Milne, P. A., Moody, J. L., and Merrill, J. T.: Transport of ozone and pollutants from North America to the North Atlantic Ocean during the

Total ozone over oceanic regions

M. C. R. Kalapureddy et al.

Title Page

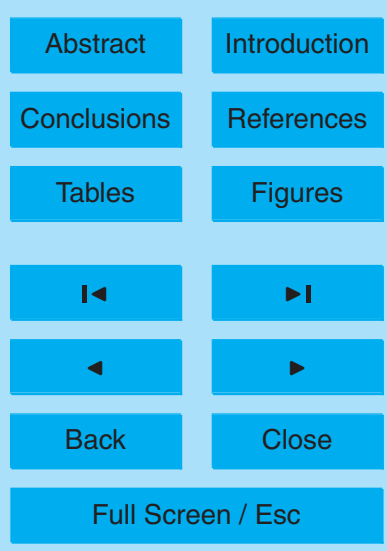

Printer-friendly Version

Interactive Discussion 
1996 Atmosphere/Ocean Chem-istry Experiment (AEROCE) intensive, J. Geophys. Res., 104, 26 219-26233, 1999.

Schultz, M. G., Jacob, D. J., Wang, Y., Logan, J. A., et al.: On the origin of tropospheric ozone and NOx over the tropical South Pacific, J. Geophys. Res., 104, 5829-5843, 1999.

5 Singh, H. B., Viezee, W., Chen, Y., Bradshaw, J., et al.: Biomass burning influences on the composition of the remote South Pacific troposphere: Analysis based on observations from PEM-Tropics A, Atmos. Environ., 34, 635-644, 2000.

Singh, H. B., Gregory, G. L., Andersen, B. E., Browell, E. W., et al.: Low ozone in the marine boundary layer of the tropical Pacific Ocean: Photochemical loss, chlorine atoms, and 10 entrainment, J. Geophys. Res., 101, 1907-1917, 1996.

Tatsumi, Y., Makino, Y., and Jensen, J.: Aircraft measurements of tropospheric ozone over the western Pacific Ocean, Atmos. Environ., 30, 1763-1772, 1996.

Trainer, M., Parrish, D. D., Goldan, P. D., Roberts, J., and Fehsenfeld, F. C.: Review of observation-based analysis of the regional factors influencing ozone concentrations, Atmos.

15 Environ., 34, 2045-2062, 2000.

Weller, R., Lilischkis, R., Schrems, O., Neuber, R., and Wessel, S.: Vertical ozone distribution in the marine atmosphere over the central Atlantic Ocean $\left(56^{\circ} \mathrm{S}-50^{\circ} \mathrm{N}\right)$, J. Geophys. Res., 101, 1387-1389, 1996.

World Meteorological Organization (WMO): Scientific assessment of ozone depletion: 2002, in WMO Global Ozone Research Monitoring Project, Rep. 47, pp. 1.1-1.83, Geneva, Switzerland, 2003.

ACPD

8, 3143-3162, 2008

Total ozone over oceanic regions

M. C. R. Kalapureddy et al.

Title Page

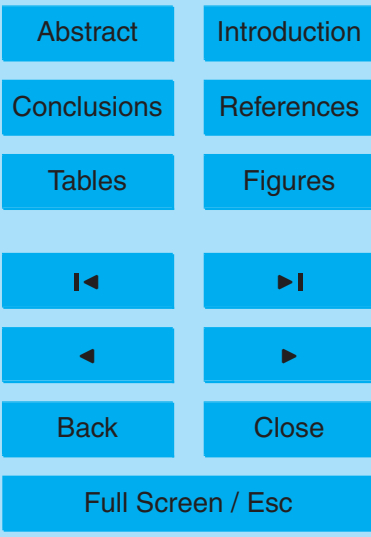

Printer-friendly Version

Interactive Discussion 


\section{ACPD}

8, 3143-3162, 2008

\section{Total ozone over} oceanic regions

M. C. R. Kalapureddy et al.

Table 1. Mean values of total column ozone, AOT and Precipitable water over the oceanic region around Indian sub-continent and over the sub regions.

\begin{tabular}{llll}
\hline Region & Ozone (DU) & WV $(\mathrm{cm})$ & AOT 1020 \\
\hline Bay of Bengal (BoB) & $287.70 \pm 10.27$ & $2.25 \pm 0.56$ & $0.10 \pm 0.06$ \\
Indian Ocean (IO) & $302.35 \pm 09.44$ & $3.25 \pm 0.53$ & $0.08 \pm 0.05$ \\
Arabian Sea (AS) & $303.98 \pm 10.23$ & $2.22 \pm 0.44$ & $0.09 \pm 0.07$ \\
Overall & $297.98 \pm 12.61$ & $2.44 \pm 0.64$ & $0.09 \pm 0.06$ \\
\hline
\end{tabular}

Title Page

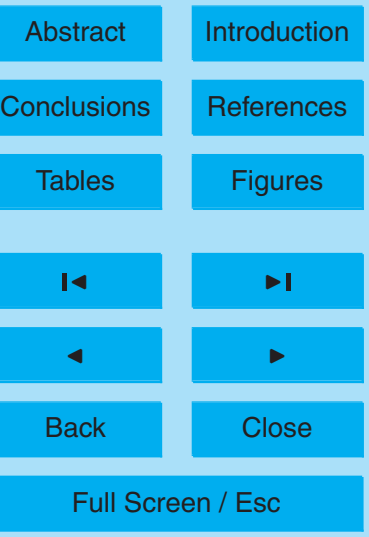

Printer-friendly Version

Interactive Discussion 


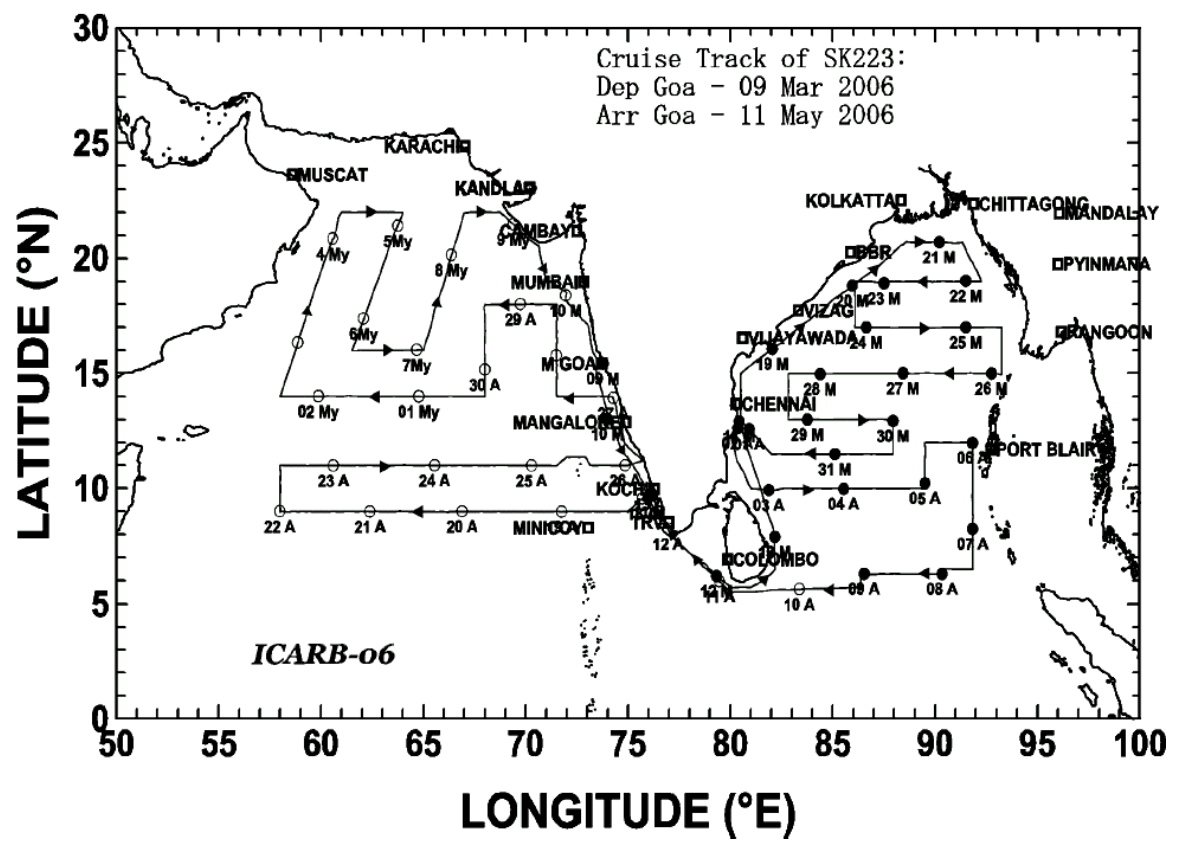

Fig. 1. Cruise track of the Research Vessel Sagar Kanya for ICARB06 experiment during 09 March to 11 May 2006.

\section{8, 3143-3162, 2008}

\section{Total ozone over} oceanic regions

\section{C. R. Kalapureddy et al.}

\section{Title Page}

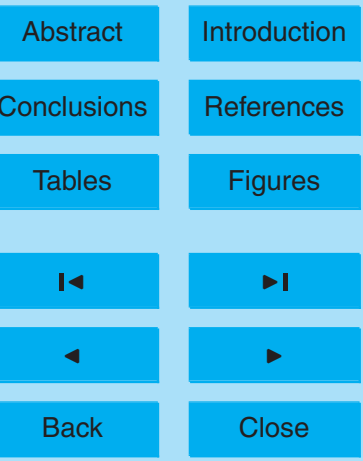

Full Screen / Esc

Printer-friendly Version

Interactive Discussion 
Ozone (DU)

N N

$\frac{\omega}{v}$

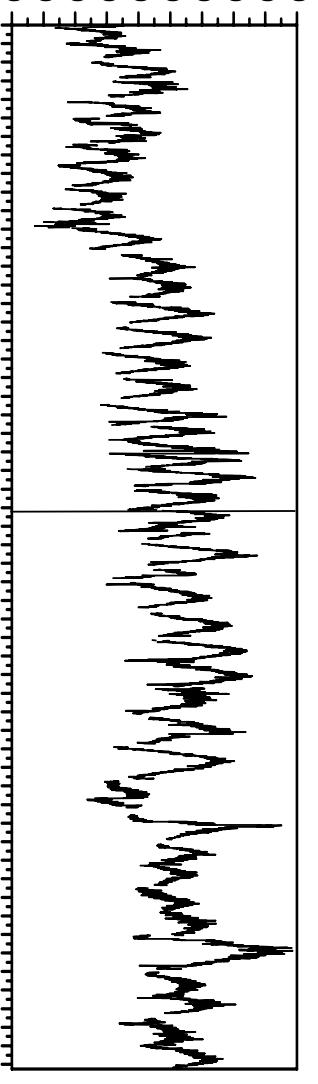

ymdd hhmmss 6319023501 6320020610 $6321013430=$ 6323012145 6325060712 $6326062656=$ $6327054023-$ $6328042713=$ 6329042435 6331014959 6331111003 6401073631 6402060337 6403021848 6403114040 6404080516 6405042933 6406005210 6406101918 6407061147 6408065804 6409061951

6412014119

64121100
-64180917

亏ౌ' 6420031833

त) 6422024956 6422102119 6423053022 6424015945

6424102530

6425070755

6427040038

6427114930

6428073819

6429025025

6429100106

6430114015

6501055258

6501133430

6502105129

$6503104120=$

6504075756

6505052825

6506083059

6507021815

6507102244

6508103334

6509051225

6510105926
그 6418091701
Ozone (DU)

N $\tilde{N}$ ป

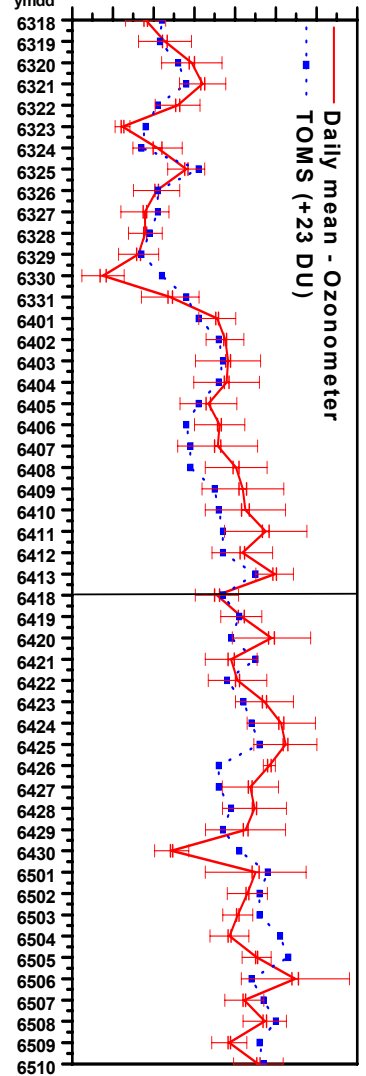

6510

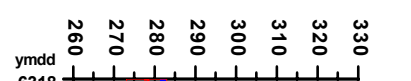

客. 


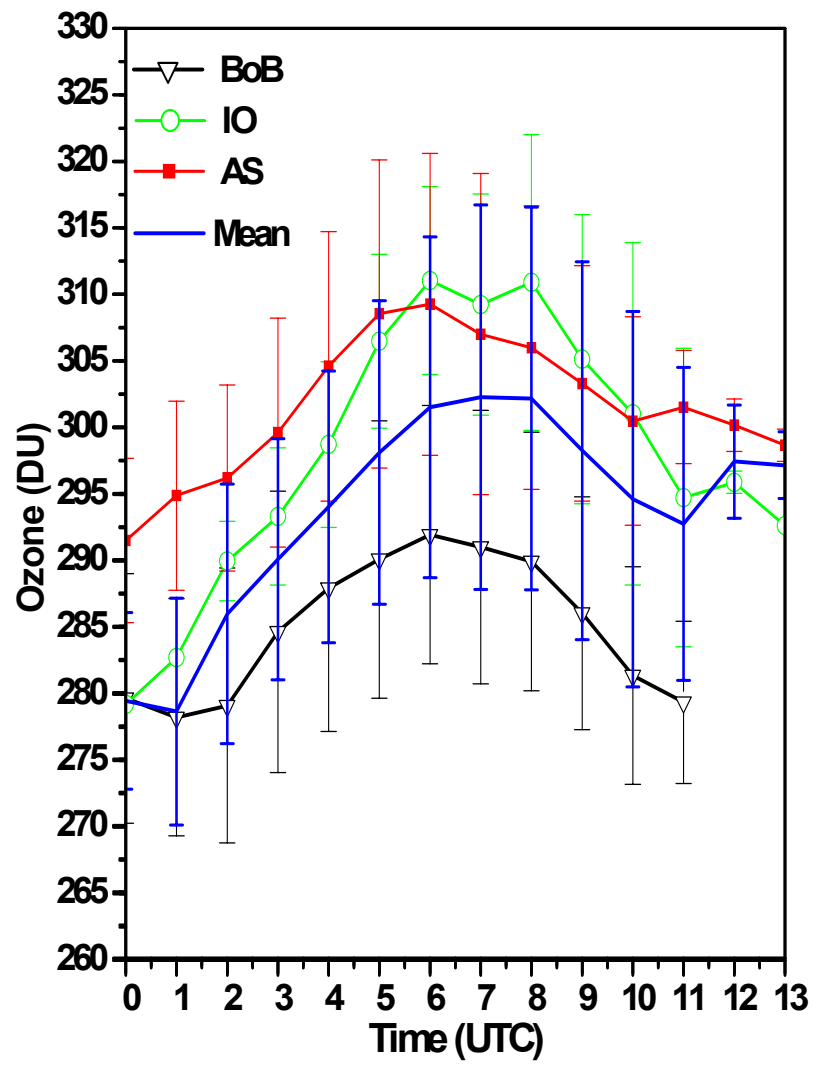

Fig. 3. Mean daytime temporal variation of total column ozone over Bay of Bengal, Arabian Sea, Indian Ocean and over the entire oceanic region (Vertical bars denote standard deviation).

\section{8, 3143-3162, 2008}

Total ozone over oceanic regions

M. C. R. Kalapureddy et al.

Title Page

Abstract

Introduction

Conclusions

References

Tables

Figures

14

4

Back 


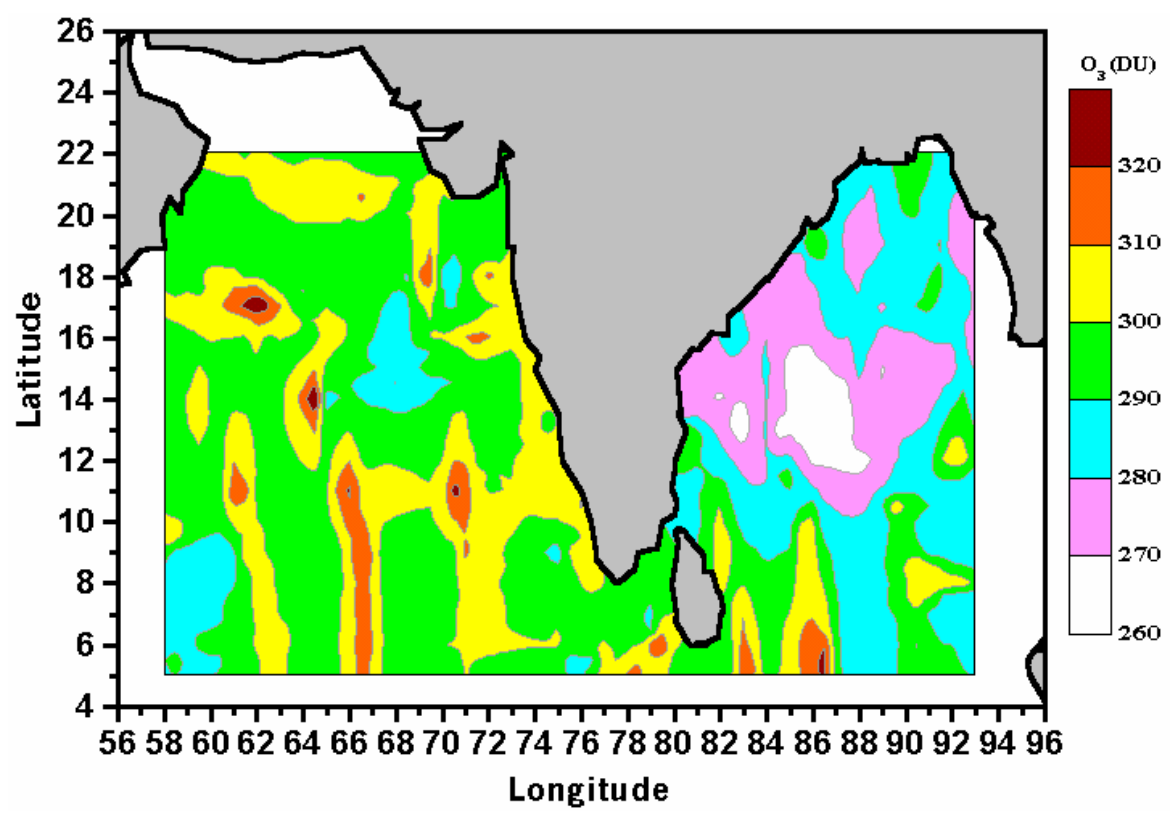

Fig. 4. Spatial distribution of total column ozone over the oceanic region surrounding the Indian sub-continent.
ACPD

8, 3143-3162, 2008

Total ozone over oceanic regions

M. C. R. Kalapureddy et al.

Title Page

Abstract

Introduction

Conclusions

References

Tables

Figures

14

Back

Full Screen / Esc

Printer-friendly Version

Interactive Discussion 


\section{ACPD}

\section{8, 3143-3162, 2008}

\section{Total ozone over oceanic regions}
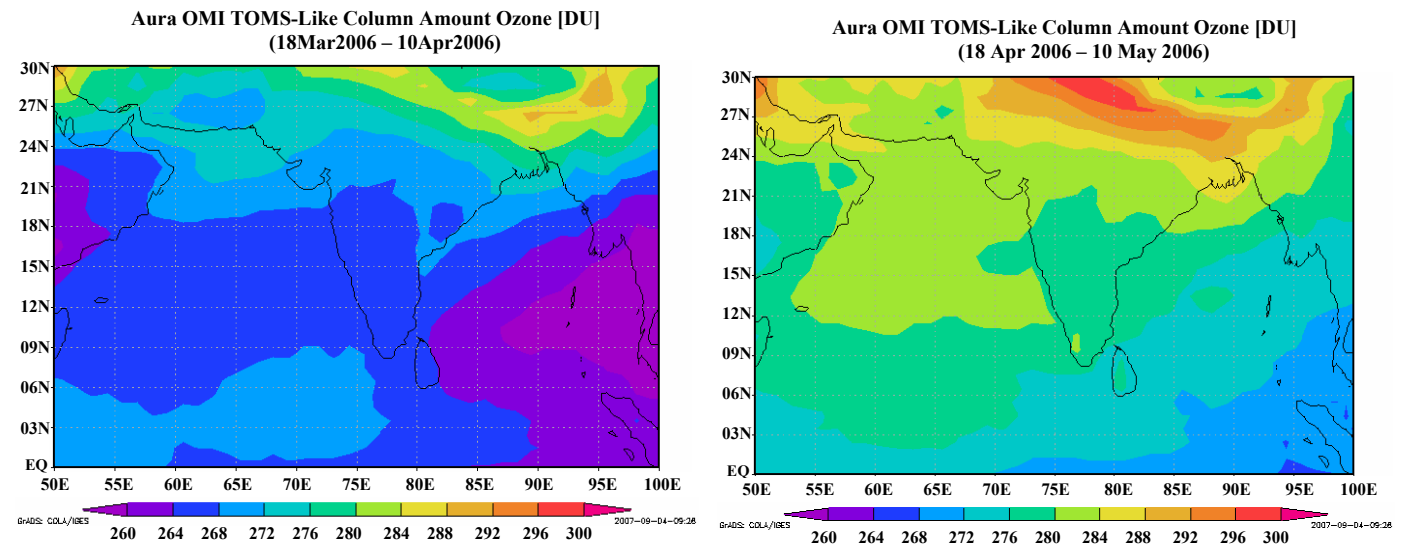

\section{C. R. Kalapureddy}

et al.

\section{Title Page}

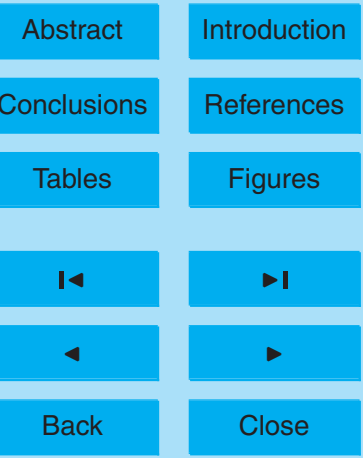

Full Screen / Esc

Printer-friendly Version

Interactive Discussion 


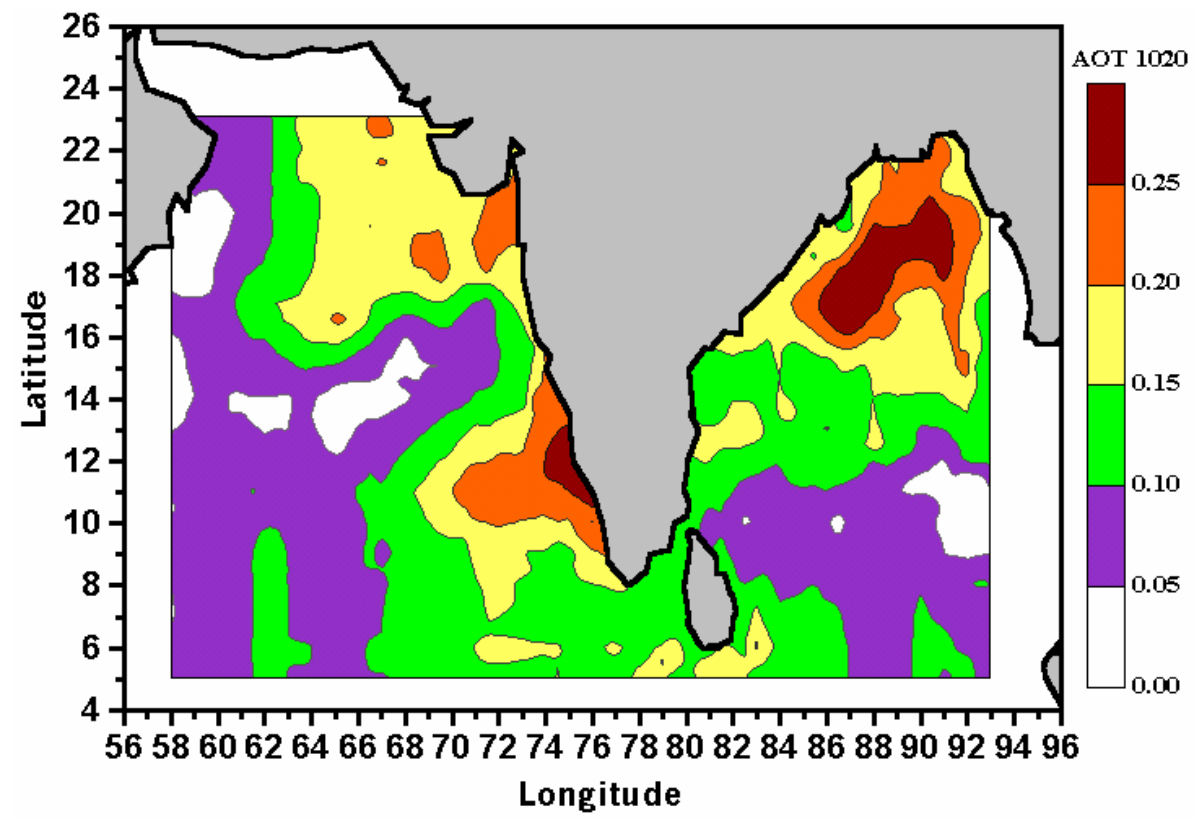

Fig. 6. Spatial distribution of Aerosol Optical Thickness (at $1020 \mathrm{~nm}$ ) over the oceanic region surrounding the Indian sub-continent.
ACPD

8, 3143-3162, 2008

Total ozone over oceanic regions

M. C. R. Kalapureddy et al.

Title Page

Abstract

Introduction

Conclusions

References

Tables

Figures

14

4

Back

Close 


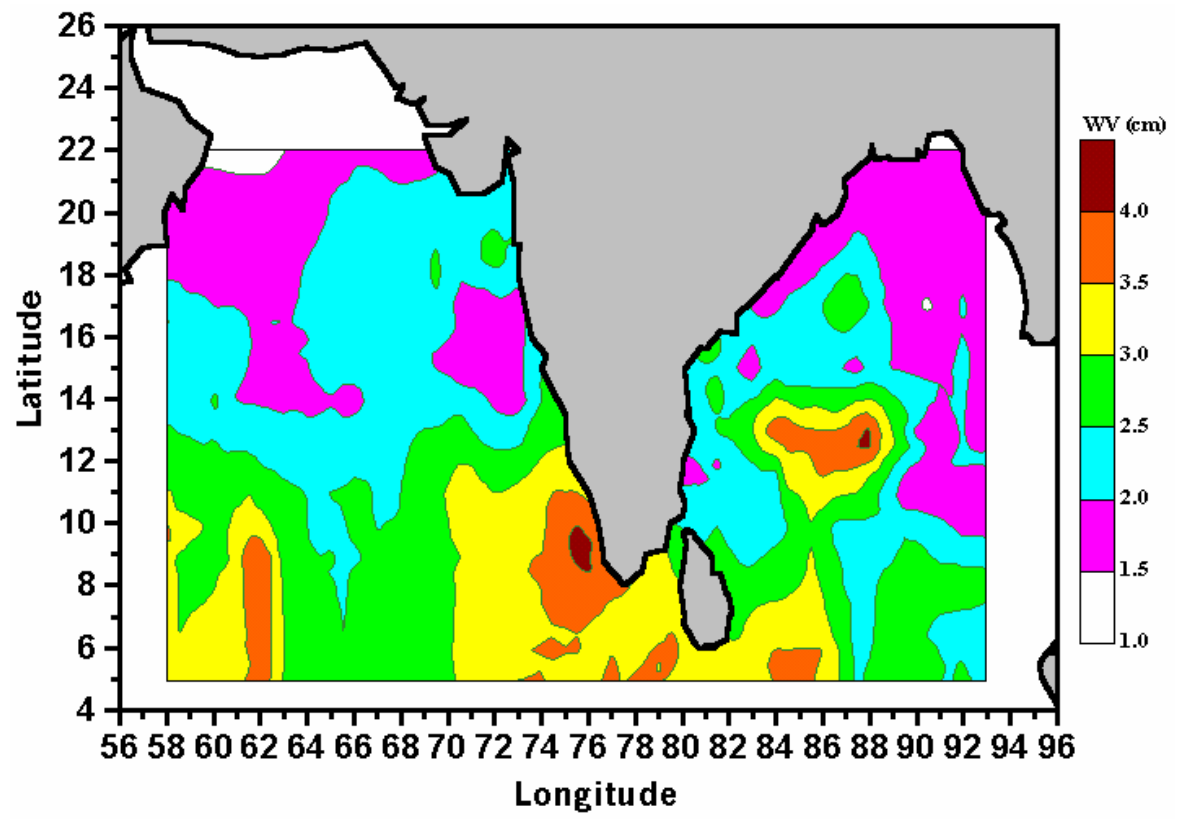

Fig. 7. Spatial distribution of Precipitable Water (Water Vapor) over the oceanic region surrounding the Indian sub-continent.
ACPD

8, 3143-3162, 2008

Total ozone over oceanic regions

M. C. R. Kalapureddy et al.

Title Page

Abstract Introduction

Conclusions References

Tables

Figures

14

4

Full Screen / Esc

Printer-friendly Version

Interactive Discussion 